\title{
The Argentine Dictatorship and Labor (1976-1983): A Historiographical Essay
}

\author{
Victoria Basualdo \\ AEYT FLACSO-CONICET
}

\begin{abstract}
This article aims at briefly reviewing some of the main contributions on the transformations and role of the labor movement during the dictatorship in Argentina from 1976 to 1983. The analysis of the historiography will distinguish three main sub-periods: the 1980s, marked by the transition to democracy in Argentina; the 1990s, a decade during which neoliberal reforms were applied with full strength; and the post 2001-crisis, a time of economic growth and complex transformation of the academic sphere. It will examine approaches to two different complex and heterogeneous actors: the working class, its political and social role, as well as the labor force; and the trade-union movement, as the institutional organizations supposed to represent labor interests. In dialog with the historiographical analysis, the last part of the article will summarize some of the main existing open questions, as well as the possibly fruitful lines of research ahead.
\end{abstract}

The dictatorship that ruled Argentina from March 24, 1976, to December 10, 1983 , is well-known around the world because of its record of massive human rights violations. Figures about the repressive legacy of the military Juntas are eloquent: An estimated thirty thousand people disappeared; thousands of political prisoners were tortured, murdered, and exiled; hundreds of children were abducted from those who were being forcibly disappeared, along with systematic theft of property and real estate; these are among the crimes denounced by human rights organizations. Many of these crimes were prosecuted by the Argentine judiciary system in the historical 1985 trial that confirmed the responsibilities in the atrocities perpetrated. ${ }^{1}$

But if this legacy of human rights violations is well known, the interpretations of the causes, meaning, and consequences of the dictatorship are still up for debate, not only in the historiography but also in public political and social spheres. Mainstream interpretations mostly focused on political dimensions, underlining particularly the role of the armed forces and their fight against political organizations and guerrilla movements. The analysis of the role of the working class or the labor movement in this period has for decades occupied a relatively marginal place within the academic literature on the issue, despite the fact that at least one third of the victims were workers. However, there have been throughout the period significant contributions that could considerably enrich the predominant views about the 1976 coup and the military dictatorship. 
The aim of this article is to briefly review some of the main contributions on this topic, as well as to outline a future research agenda. The analysis of the historiography will be organized chronologically, which allows us to analyze some of the connections with other political, economic, social, and academic processes. It will distinguish three main sub-periods: the 1980s, marked by the transition to democracy in Argentina; the 1990s, a decade during which neoliberal reforms were applied with full strength; and the post 2001-crisis, a time of economic growth and complex transformation of the academic sphere. The text will examine approaches to two different complex and heterogeneous actors with complexities and tensions: on the one hand, the working class, both in terms of its political and social role, as well as in its economic dimension as labor force; on the other hand, the trade-union movement, as the institutional organizations supposed to represent labor interests. In dialog with the historiographical analysis, the last part of the article will summarize some of the main existing open questions, as well as the possibly fruitful lines of research ahead.

During the 1980s, and especially after the transition to democracy in 1983, there were relevant contributions about different aspects concerning labor and the dictatorship, partly building on approaches written at the time of the "Process, as the dictatorship called its counterrevolution." Labor repression also became an important topic both in the Nunca Más, the report made by the Comisión Nacional sobre la Desaparición de Personas (CONADEP), the Argentine truth commission in 1984, and in the "Juicio a las Juntas" trials in 1985 , which prosecuted not only the members of the military Juntas but also the most prominent leaders of the guerrilla organizations. The first of its type in Latin America, the trial was quite significant in political and social terms, for it proved, publicized, and punished the crimes of the dictatorship. However, in the ensuing years and under strong military pressure, this human rights policy was countered by two laws (Laws No 23,492 in 1986 and No 23,521 in 1987) establishing that the military of inferior rank to the military Juntas were not to be held responsible for their acts because they were following orders. Thus, they could not be tried, and there was a specific deadline for suing the terrorist state for the atrocities committed, after which legal actions were frozen.

Both in the Nunca Más truth commission and the trial proceedings, it became clear that workers and union leaders had been a major target of the repressive policies, and that labor discipline and control had been among the key goals of the dictatorship. Also, some of the most extreme cases of labor repression, such as those related to the companies Acindar, Ledesma, Mercedes-Benz, Ford Motor Argentina, Astarsa, among others, were already denounced, acknowledged and analyzed. However, all of these elements were considered of secondary importance compared to the central conflict acknowledged in this period in order to explain the coup and the dictatorship: the confrontation between the armed forces and the guerilla organizations.

In this context of debate about the dictatorship and its legacies, several contributions illuminated aspects related to labor and economic and social change. ${ }^{2}$ 
A couple of early articles by Francisco Delich emphasized the impact of repression against the working class, referring to the thousands of labor activists and leaders who had been murdered, imprisoned, disappeared, or forced in to exile. ${ }^{3} \mathrm{He}$ also analyzed the various policies focused on control and discipline within the shop-floor during this period, the prohibitions in terms of trade-union activity, and the strict control during the hiring process, as well as the intelligence activities within the factories in order to persecute labor and political activism. An important contribution is his emphasis on the international sphere, that in his view "was of unusual importance, and the actions developed there had unexpectedly relevant consequences." "However, while these early works were useful to underline the impact of repression against the working class, they also contended that labor had been immobilized during this period, and that there was during this period a clear turning point in terms of struggle and action, contributing to foster an image of complete detention of labor conflict, a characterization that was strongly challenged both by contemporary studies, such as those by León Bieber for example, and by later studies. ${ }^{5}$

A book published by Alvaro Abós in the early years of the transition to democracy focused the attention first on the historical importance of the tradeunion movement and secondly on the transformations that this movement suffered during the dictatorship. ${ }^{6}$ Based on his experience as a labor lawyer and his first-hand knowledge of different sectors of the labor movement, Abós documented the general offensive against labor, analyzed the active intervention of the dictatorship in terms of labor norms, and analyzed some key cases such as the kidnapping and disappearance of Oscar Smith, the Secretary General of the electricity union (Light and Power) in February 1977.

Shortly after, the publications by Arturo Fernández made significant contributions by integrating an analysis of the labor and economic policies developed by the dictatorship and their impacts on labor, also referring to, although more limitedly, the consequences of repressive policies. ${ }^{7} \mathrm{He}$ was among the first that tried to quantify and offer lists of the trade-union organizations that had been subjected to military rule, made references to changes in labor legislation and practices, and analyzed the dynamics of labor conflict during the period. He also devoted quite extensive attention to the international sphere, providing a first-hand view of the importance of the ILO as an arena of debate and exposure, as well as a preliminary reference to other major actors of the international labor movement.

In the late 1980s, with the publication of a book and an article, Pablo Pozzi strongly emphasized that workers' and union's agitation during the dictatorship not only was intense, but also decisively contributed to the failure of the regime's objectives with regards to the organized labor movement. ${ }^{8}$ Pozzi's contributions have the merit of analyzing labor conflict, not only in its traditional forms but also underlining the existence of "underground" practices at the shopfloor that were underestimated or forgotten by most approaches to this period. These forms of protest were typically developed by groups of workers with reduced coordination and limited impact. They included slowdowns (alleging 
"reluctance" - desgano - and sadness), partial interruption of production, sabotage, and a broad range of creative measures oriented towards workers' organization and expressing opposition to business' offensive. This author considers that these "new forms of protest" resulted from the learning process of past experiences, such as the Peronist Resistance during the first years after the 1955 coup. ${ }^{9}$ Beyond any possible controversy about their origin, Pozzi's studies proved that these ways of protest were especially important, as while they respected the letter of the law and in some cases the new practices imposed, they subverted their spirit, becoming an increasingly evident challenge to the regime. ${ }^{10}$

These publications expressed a debate within the historiography concerning the responses of workers, shop-floor representatives, and union leaders that included a spectrum of interpretations between two opposing approaches. While views such as Delich's emphasized the impact of repression and therefore suggested that from 1976 to 1981 the Argentine working class and its unions were stagnant and inactive and that both unions and workers exhibited a lesser amount of power than they had at any other moment in Argentine history, ${ }^{11}$ Pozzi, along with contributions such as those of Falcón, Fernandez, and James Petras among others, stressed the existence of a wide range of responses by workers and the labor movement. ${ }^{12}$ It is possible to extract elements from the different lines of interpretation towards a complete understanding of the process. As Delich argued, the policies of the military dictatorship dramatically affected workers causing the most profound change in the history of the labor movement since the 1940s, although his characterization of labor immobility proved incorrect. ${ }^{13}$ At the same time, as Pozzi explained, although labor and economic policies, as well as repression, were successful at demobilizing part of the working class, other sectors carried out a wide range of responses to the dictatorship's anti-labor policies. Protests against the policies that affected workers' conditions of life and work took place both in Argentina and abroad, and included rank-and-file and leadership actions featuring both traditional labor measures and new ways of protest adapted to this particular context of repression.

The 1990s was a difficult decade for labor studies in Argentina as in many other regions, due not only to the structural transformations and regressive labor reforms in times of increasing unemployment, but also to the regressive changes in the scientific spheres that reduced funding and research possibilities, in a context of state restructuring and significant budget cuts in government spending in education and scientific activities. In terms of the discussion about the dictatorship and human rights policies, the decrees of executive pardon by President Carlos S. Menem in 1989 and 1990 attempted to close the matter of past human rights violations, promoting a policy of "reconciliation." In this context, there were different attempts to appeal to other national and international courts, as well as to promote the so-called Truth Trials, Juicios por la Verdad, in Argentina in 1998, in charge of the Federal Judiciary Chamber, with no penal consequences. In both frameworks, there was new emphasis on 
the anti-labor character of the dictatorship: The Central de los Trabajadores de Argentina made a presentation in Spain before Judge Baltasar Garzón in 1998 providing the names of thousands of disappeared workers and underlining the persecution against shop-floor representatives and trade-union leaders. At the same time, in the context of the Truth Trials there were new testimonies and evidence about many cases that had not been approached before.

Despite this regressive context in terms of the process of penal justice, there were interesting research contributions in several directions. Although labor history became an increasingly marginal field, there were historians who continued this analysis, and focused particularly on relevant case-studies combining a shop-floor and regional perspective. Prominent among them are the contributions by Alejandro Schneider and others on the Northern industrial belt that illustrated both the strong impact of repression and the different forms of organization and protest, as well as that of María Cecilia Cangiano about Villa Constitución. ${ }^{14}$ Other contributions aimed at making progress foster a comparative analysis of dictatorships and the labor movements in the region, such as the book coordinated by Barrera and Fallabella in 1990 that aimed at connecting the cases of Argentina, Brasil, and Chile. ${ }^{15}$ The articles on Argentina included one study by Delich in the same analytic line previously reviewed and another by Thompson and Gallitelli that approached several key aspects of the labor policies of the dictatorship, as well as effects that had been scarcely identified before, such as the fragmentation of the working class during this period and the impact of the policies of industrial promotion that relocated factories from the populated industrial belts with a long history of labor organization to new areas with no significant labor organization and networks. ${ }^{16}$

Particularly interesting in terms of its aim and scope was a book by Paul W. Drake, which studied the relationship between the labor movements and dictatorships in the Southern Cone (Argentina, Chile, and Uruguay, with supplementary references to the cases of Brasil and Greece) in a comparative perspective. Drake provides valuable information and analysis on the cases he analyzed using statistical information about economic and social transformations, legal material, and norms about the trade-union movement, as well as several institutional sources. Based on this he firmly argued that "the dictatorships studied here varied a great deal in their setting and history, but an essential common thread was their reaction against the working class." In his view, "in every case, the pivotal role of labor should not be underestimated" and "in many ways, the antilabor stance of these despotisms defined their raison d'etre."

Despite this very relevant conclusion, he could not explain clearly the reasons of this anti-labor stance. He ruled out a revolutionary perspective, making clear that "this study will not ask why the working class failed to carry out a social revolution. Such a rare event was always unlikely in Chile and was never on the horizon in Argentina or Uruguay." He considered instead that "both the fearful perceptions of right-wingers and the hopeful scenarios of left-wingers were incorrect," as "democratic countries with large middle classes and professional armed forces were not susceptible to an 
insurrection or fundamental transformation by leftists." 17 Some of the proposed causes to explain the dictatorship and its legacy of human rights violations were the misleading propaganda that provoked an unfounded fear of Communism or fear for the actions of a radical minority, which do not seem satisfactory as causal explanations. ${ }^{18}$ Discussing with other perspectives that seem to assume that the history of the combative sectors reflects the evolution of the entire working class, Drake seemed to consider the radical sectors negligible, failing to fully explain the military and business concern for labor conflict and organization. Contributions like his, as well as others such as Ronald Munck, who also dealt with this topic in the late 1990s and stressed the importance of the offensive against labor by the dictatorship that "launched an all-out attack that aimed at destroying both the legal and extralegal basis of power of labor," ${ }^{19}$ were very important to demonstrate the regional and international dimensions of the offensive against labor, and to stress the relevance of looking at the history of dictatorships from this viewpoint, even when they were not able to fully account for the causes of the process.

At the turn of the century, in a context of profound institutional crisis that implied drastic transformation of economic and social relations, the public debate over the impact and consequences of the dictatorship underlined the economic and social effects of the structural reforms. ${ }^{20}$ The political process that led the way out of the crisis from 2003, when Néstor Kirchner was elected president, introduced relevant changes. First, the judicial situation of prosecution of human rights violations changed substantially, building on a long process of struggle and organization of various organizations, prominently the human rights movement. After the decision of a court of justice in 2001, a pronouncement from Congress and the development of a strong set of policies by the Executive branch from 2003 onwards, and the 2005 ruling of the Supreme Court of Justice deeming the laws that had halted the trials in the late 1980s unconstitutional, the trials restarted from 2005 onwards in multiple points of the country. Second, labor conflict and trade-unions regained importance and played a central role in politics and the economic and the social struggles, reversing the previous tendencies. Third, the scientific institutions in Argentina and the academic field experienced important transformations.

All of this influenced the field of labor history, which grew considerably and expanded in many ways. Within historical studies there was a growing claim in defense of the legitimacy and importance of contemporary history, also called "recent history," which had been up to then severely questioned and restricted to reduced spaces. This was a time also of increasing interest in the studies on memory and oral history as a feasible and valuable approach. With regards to the specific topic of labor and the 1976-1983 dictatorship, in dialog with the general approaches provided in the 1980 s and $1990 \mathrm{~s}$, there were several researchers that approached case-studies, which focused more closely on the shop-floor, but also were useful to discuss, confirm, or even contradict previous characterizations. This kind of analysis focused on in-depth case-studies had been quite difficult before, not only because of the typical challenges of 
attempting to write history from below in communities that do not have the possibilities or habits to preserve documents and archives, but also because, due to the censorship and repression during late 1970s and early 1980s, many of the existing archival collections had been destroyed or made unavailable. This new wave of historical contributions on labor and the dictatorship was possible because new archives and repositories were opened in different ways.

Prominent among them was the first intelligence archive made available to the public, that of the Intelligence Direction of the Province of Buenos Aires (DIPBA), managed by the Comisión Provincial por la Memoria in La Plata, Province of Buenos Aires, which opened indirect access to their archives to researchers. $^{21}$ Although to access all documents related to the 1976-1983 period it is necessary to receive authorization from the Federal Chamber of Appeal, as this is documentation still used in trials, this authorization is generally granted to researchers and therefore this archive made possible access to previously unavailable intelligence reports and documents (in many cases, confidential) on labor activism and militancy that were of key importance to reflect the kind of activity and organization prevailing at some large factories of the Province of Buenos Aires and even beyond it. ${ }^{22}$ Also, the DIPBA archive has the police files on many unions, complete with copies of union publications and police intelligence reports, in some cases enabling unions to reconstruct their history. Also, very important is the documentation center CEDINCI (Centro de Documentación e Información sobre la Cultura de Izquierdas en la Argentina), which holds entire collections of labor, social and political materials, leaflets, and political publications of different labor and political organizations that were of great use documenting the labor struggle and organization in the factories. $^{23}$

Also, researchers managed to gain different kinds of access, in many cases through active and continuing struggle, to a variety of state archives, including the Archivo Nacional de la Memoria, founded in 2003 by Executive decree, Archivo General de la Nación (particularly the section Archivo Intermedio), as well as many archival documents from the different governmental institutions or ministries, such as Defense, Labor, or Foreign Relations ministries. Also, some human rights organizations archives, such that of the Centro de Estudios Legales y Sociales and other umbrella organizations such as Memoria Abierta became organized and open to the public, while regional archives and museums, such as the Museo de la Memoria in Rosario or the Archivo Provincial de la Memoria (D2 Archive) in Córdoba, as well as many other institutions and memory centers, were crucial to allow different levels of access to new sources throughout the country. Repositories from universities and research centers, such as those of the Area of Economics and Technology of FLACSO and the CISEA-CESPA at the University of Buenos Aires, for example, also provided significant material about business trajectories and economic transformations. Archives of trade-union organizations are still rare and difficult to access, as most of the organizations do not have a policy of preservation and access to their own papers that are not organized in a professional 
manner. However, many researchers managed to gain partial access to some trade-union repositories and personal archives that also provided key materials.

Business archives were the exception and remained overwhelmingly closed and inaccessible concerning documents for this period. Finally, the use of oral histories and interviews increased during this period, not only because of the growing legitimacy of these sources and these approaches and methodologies within the academic field, but also due to the progresses of the penal prosecution of the human rights violations and increasing acceptance of these issues, many sectors were more willing and able to speak about their experiences within a research framework.

Perhaps the most striking feature of historiography since the turn of the century is that based on these and many other sources coming from national, regional, and local archives, it was possible to focus on new case-studies located in various regions of the country. For the northern industrial belt, which extends from the north and west of Buenos Aires to the South of Santa $\mathrm{Fe}$, there were new contributions about the cases of the shipyards Astarsa and Mestrina, the automobile companies Ford and Mercedes-Benz, the steel mill Dálmine Siderca in Campana, the ceramics companies Lozadur and Cattaneo, and the case of the textile firm Grafa, among others. ${ }^{24}$ In the Province of Santa $\mathrm{Fe}$, in the area of Rosario, there are studies of Acindar in Villa Constitución, SOMISA in San Nicolás and also contributions about the dynamics of conflict in the region, and the labor policies developed by the industrial leadership. ${ }^{25}$

There also have been, in this decade, studies about the southern industrial belt, from the south of Buenos Aires City to La Plata, Berisso, and Ensenada. Some of the cases analyzed were the food industry plant of Molinos Río de la Plata in Avellaneda, the textile and shoe company Alpargatas (plants in Barracas and Florencio Varela), the steel mill Propulsora Siderúrgica (Techint group), the shipyard Río Santiago, the meatpacking company Swift, the chemical textile company Petroquímica Sudamericana, among others, such as SIAT Valentín Alsina and the YPF oil refinery in Ensenada. ${ }^{26}$ In the interior of the Province of Buenos Aires, there are studies about the cement company Loma Negra (plants in Olavarría and Villa Cacique), the graphic workshop of the newspaper "La Nueva Provincia," and the auto-part company Metalúrgica Tandil, among others. ${ }^{27}$

In the case of Córdoba, there are studies about the Fiat plants during the dictatorship, about the electrical company EPEC, and other more general approaches about the impact of repression on workers of many economic activities. $^{28}$ For the case of the north-eastern region of the country, there are some studies about the repression of workers involved in the Agrarian Leagues, and also about the yerba mate and tea company Las Marías. ${ }^{29}$ With regards to the north-western region of the country there are studies about the sugar mills Ledesma (Jujuy), Concepción, and La Fronterita (Tucumán), about the mining company Minera Aguilar (Jujuy), and the transport company La Veloz del Norte (Salta). ${ }^{30}$ In the case of Patagonia, there are studies about 
Chilean workers exiled in Patagonia, as well as different factories of the northeast of Chubut, among other cases. ${ }^{31}$

As research expanded thematically, geographically, and in terms of methodology, perspective, and sources during the last decade and a half, new views and debates emerged. These new case-studies illuminated new perspectives and findings in many directions, some of which will be briefly reviewed here. One of the topics that had not been previously studied in depth was the conflicting, tense, and complex relationship between labor struggles, trade-union activity, and guerrilla actions in specific activities and territories during the $1970 \mathrm{~s} .{ }^{32}$ It was an important achievement then to connect the fields that were focused on labor and guerrilla organizations that had long-term developments, but that had had very little connection.

Another remarkable line of research in many of these new contributions was the study of shop-floor organization, which introduced complexities in views previously centered around large, nationally based trade-union organizations and leaders, and the exploration of the connections between structural economic changes and labor relations, as well as forms of organization, contemplating the particularities and specificities. Several of these studies explored the transformations at the level of the shop-floor, particularly focusing on the role of the shop-stewards and comisiones internas; many of the casestudies confirmed that this level of organization was very important from the second period of import substitution industrialization that extended from the mid-1950s and mid-1970s to the structural transformations of the 1970s. They showed that they had suffered from the economic, labor, and repressive policies of the dictatorship, although in very different ways according to the cases that presented differences in business trajectories, history of trade-union organization, and also different processes of transformation and repression. ${ }^{33}$

There were also important sociological contributions on the social profile of the victims of the dictatorship, reassessing judicial information, and proposing new conceptual frameworks and debates. ${ }^{34}$ Additionally, many of these studies attempted to connect the strong development of the field of memory studies with that of labor history. While initially the results of these efforts were limited, over time there was an important, positive change that generated a number of contributions aimed at analyzing the ways in which workers remembered the time of the dictatorship, focusing on those who had not been labor or political militants, and not only regarding aspects related to the working time at the factories, but also to many other aspects of everyday life. ${ }^{35}$

In the field of the studies on exile and migration, there were also new contributions that illuminated aspects of the exile of workers and trade-union leaders, contributing to a growing field in which the sphere of labor, however, had received little attention previously. ${ }^{36}$ These contributions also underlined previously disregarded phenomena, such as the importance of internal migration or displacement within the country as a strategy to escape from persecution, particularly in the case of sectors that had limited or no access to international connections or lacked the necessary funds to go abroad. ${ }^{37}$ The institutional 
international dimensions of this history, although briefly and basically covered in different contributions in the 1980s and 1990s, were the object of increasing attention during the last decade. There were contributions on the international campaign developed by different sectors of the labor movement against the dictatorship, the role of the ILO, and the world labor confederations, as well as the impacts of these processes on national events. ${ }^{38}$ Quite recently, other contributions focused on the role played by conservative sectors of the union leadership in support of the dictatorship, both within national boundaries and abroad. ${ }^{39}$

There was important progress in an issue that had been debated from the time of the dictatorship and the transition to democracy: business responsibility for labor repression. In this field major advances have been made in the last years, from initial individual research projects about a few cases in depth, to a major study carried out by four organizations: the Area of Economics and Technology of FLACSO, the Centro de Estudios Legales y Sociales (CELS), and two governmental offices within the Ministry of Justice and Human Rights: the Programa Verdad y Justicia, and the Secretary of Human Rights. ${ }^{40}$ From 2014 to 2015 these four institutions put together an interdisciplinary team of twenty researchers and coordinators, which analyzed twenty-five cases of companies in different regions of the country. The main conclusion of this study was that the process of militarization of factories and the amount of evidence about direct involvement of businessmen in concrete and specific repressive practices, as well as the existence of places of detention and the torture of workers within the boundaries of the private companies in five of the twenty-five cases, call for a reconsideration of the concept of "complicity" to replace it with "responsibility" of companies and businessmen for the repression of workers and their organizations. ${ }^{41}$ This study is also a good example of another interesting process that took place in these years: the increasing, although not simple or fluent, dialog between historical analysis and the judicial process. The contact between these different and often conflicting approaches took many forms, including the fact that many researchers were summoned as "expert witnesses," providing interesting insights to the trials.

Maybe the most striking pending issue in recent studies is the relatively minor importance given so far to the gender dimension of this history. Although they are slowly becoming more important in general historiography concerning labor and the trade-union movement in Argentina, gender relations have not been systematically taken into account in most of the summarized studies about this period, with some valuable exceptions to the rule and particular studies focused on women workers. ${ }^{42}$ To further develop this dimension, including in the general analysis, seems to be one of the most urgent needs, both to analyze the policies of the dictatorship and to see whether they were gender-biased, but also in terms of the possible differential impact on the working class and the trade-union movement, as well as in the ways gender relations structured the responses and forms of organization and militancy during this period. Studies made on other countries in this same period clearly 
demonstrated the relevance and potential to explicitly make gendered labor relations visible, and this is certainly a major challenge ahead. ${ }^{43}$

In sum, there has been, in recent years, a very rich and diverse academic literature that changed the field of studies of labor and the dictatorship (1976-1983). While there have been many valuable attempts, it remains difficult to secure a comprehensive view of this field of study. ${ }^{44}$ Not only are there differences in scope, perspective, aims, methodology, and sources among these contributions, but also various lines of interpretation that are often in disagreement or debate. It is important to stress the debate among the researchers implicitly or explicitly using the concept of "consensus" or "consent" and those who, based on an analysis of power relations and in many cases also class analysis, raise questions regarding whether it is productive or adequate to use that concept not only in the general framework of asymmetrical relations between capital and labor, but also particularly in a context of strong repressive policies applied, regressive social and economic transformations and labor rights violations, issues often underestimated, that make even more questionable or unlikely to think about "freedom of choice" for labor. Therefore, these perspectives call for the clear recognition of the power relations strongly conditioning workers and unions, and the search for other possible concepts to explain a wide range of labor positions and forms of struggle. ${ }^{45}$

This accumulation of research opens new possibilities ahead. Regarding the debates of the 1980s, it became clear that it is quite productive to avoid framing the period in absolute terms, focusing instead on its complexities and tensions. While the evidence of the long-lasting impact of the strongest repressive policies on workers and the labor movements in Argentine history is undeniable, it is also necessary to look at the ways in which the dictatorship attempted to gain legitimacy, and whether the dictatorial project was in any way internalized by workers or sectors of the trade-union movements. Moving away from concepts such as "resistance," which were useful to confront initial views of labor's "total immobility" but could impose homogeneity on diverse phenomena, can be useful in studying the wide range of responses during the dictatorship. ${ }^{46}$

This could be particularly important, not only to illuminate the often forgotten episodes of organization, struggle and opposition developed by workers and trade-union leaders or organizations, but also to better explore the role played by some sectors of the trade-union movement that built connections with different sectors of the dictatorial government, due to ideological reasons and/or because they were seeking to strengthen their position at a time of profound reconfiguring of labor relations. It also seems very important to separately study two different actors, the working class and the trade-union movement, which had often been analyzed in such a close connection that they could be mistaken as one. Looking at the recent contributions, it becomes clear that it is necessary to analyze each of them separately, understanding their own particular dynamics, and taking into account, at the same time, the diversity and heterogeneity within them, avoiding drawing general conclusions based on partial cases or facts. 
The knowledge about the different forms of repression and the persecution of workers and labor leaders also increased enormously during this period, from general and all-encompassing perspectives to much more detailed, nuanced, and diverse histories. ${ }^{47}$ It became clear that in order to analyze the general patterns of repression it is necessary to take into account not only the most extreme situations of regions and cases in which atrocities were perpetrated, but also other cases in which repression had a totally different dynamic or even was subtler. The accumulated evidence shows that the dictatorship marked undoubtedly a turning point for workers and trade-union activity, but at the same time it stresses that in order to understand this complex period it is necessary, first, to include the previous years (the 1974-1976 period at least), and second, to build a longitudinal analysis of violence and the repression of workers, essential to make this time intelligible. Recent contributions are extremely useful to put the 1976-1983 era in a larger narrative in terms of both labor conflict and labor repression, and the more extensive framework of the Cold War period seems to have great potential in order to allow a more fluid dialog with other processes in Latin America and beyond. ${ }^{48}$

At the same time, many of the existing studies also remind that repression was not the only policy applied. On the contrary, even for such an anti-labor regime some structures of representation were needed, and therefore, there were also attempts to reconfigure and redirect the ways in which labor organizations worked. In terms of labor relations, both the armed forces and the business elite had to negotiate with some sectors and keep some structures in place in order to stop turmoil and try to lessen labor unrest. To study this complex balance between repression and preservation and even encouragement of some sectors and dynamics is quite an important task ahead.

Regarding lines of action of workers during the dictatorship, it is also clear that the way workers experienced the dictatorship was also diverse, and it is essential then to open the way for an analysis of the different trajectories, thinking about them not as free choices, but as products of a very complex combination of the different forms of external constraints (particularly violence and repression, but not solely), personal trajectories, and collective repertoires that have to be considered carefully and studied in detail. Concerning the tradeunion movement, it is necessary to avoid the tendency to take the part for the whole and therefore tell the story as if it were complete, though looking only at specific actors. The available contributions call for much needed research to analyze the strategies and actions of the different sectors of the labor movement: the combative ones, who are very often discarded and considered totally out of the picture, and the different sectors, from centrist positions to conciliatory and conservative ones that developed different kinds of balances between activism, conflict, and negotiation during the dictatorship.

This could be very helpful in eroding the relative isolation of the labor historiography of this period, helping to connect it with that of previous years, which had been overwhelmingly concerned with the relationship between the working class, the trade-union organizations, and the Peronist movement, a 
topic that was almost abandoned from 1976-1983. Paying attention to the different evolution of groups and tendencies within the trade-union movement, some of whom identified with left-wing and others with right-wing Peronism, would also be interesting in helping analyze the different impacts of the dictatorship on this political movement, and the contradictory and complex legacy in this matter: While the most radical and combative sectors became central targets of repression, other conservative and right-wing sectors gained influence and power during this period, all of which had a strong impact on the evolution of the Peronist Justicialista Party in the 1980s and 1990s.

It is also necessary to look much more closely at the role of the armed forces, their sectors and divisions, and their specific logics, aims, and possibilities. It became clear from the available studies that the military dictatorship, although aiming to achieve a new foundation of labor relations, had a very complex internal composition that included different sectors and actors, and was forced to limit itself in many ways, taking into account other agendas. Similarly, the relationship between the armed forces and the business elite was not an easy or univocal one, but instead a tense link with many different sectors, that experienced many transformations throughout the period. A closer study of this relationship would require conceptual insights that could make important contributions to the implicit debate around the "military" or "civil-military" character of the dictatorship, an issue that needs to be explicitly addressed from a theoretical, conceptual and historical viewpoint. In this sense, the available studies also call for an interdisciplinary approach, which means that it is crucial to establish meaningful dialog and productive, collective work in order to be able to take into account the indispensable, structural economic and social dimensions as well as the political, cultural, and subjective ones. This seems essential not only to study in depth the already mentioned actors, but also in order to include and integrate other aspects of this history that have been overlooked so far, such as the issue of gender relations in the different aspects of this history, both in terms of the working class and the trade-union movements, and the dynamics of repression, among others.

In sum, the fruitful and interesting field of studies on workers, trade-unions, and the 1976-1983 dictatorship in Argentina made quite significant contributions to the history of this period, also opening new avenues of research. Following an initial stage of comprehensive and encompassing studies, new approaches based on case-studies and in-depth analyses of specific topics provided new evidence and information, calling for new general views that would undoubtedly be key to enriching the still predominantly political views on the dictatorship with other crucial dimensions.

\section{NOTES}

1. See Sergio Ciancaglini and Martín Granovsky, Nada más que la verdad. El Juicio a las Juntas (Buenos Aires: Planeta, 1995). 
2. There were also key contributions published within the field of economic history, particularly: Daniel Azpiazu, Eduardo Basualdo, and Miguel Khavisse, El nuevo poder económico en la Argentina de los ochenta (Buenos Aires: Editorial Legasa, 1986); Adolfo Canitrot, "La disciplina como objetivo de la política económica. Un ensayo sobre el programa del gobierno argentino desde 1976," Desarrollo Económico 19(76): (1980) 453-75; Jorge Schvarzer, La política económica de Martínez de Hoz (Buenos Aires: Hyspamérica, 1987), among others.

3. Francisco Delich, "Después del diluvio, la clase obrera," in Argentina, hoy, (coord.) Alain Rouquié (Mexico City: Siglo XXI, 1982), and Francisco Delich, "Desmovilización social, reestructuración obrera y cambio sindical," in El Poder militar en la Argentina, 19761981, eds. Peter Waldmann and Ernesto Garzón Valdés (Buenos Aires: Editorial Galerna, 1983), 101-16.

4. Delich, "Después del diluvio, la clase obrera," 146.

5. León Bieber, "El movimiento obrero argentino a partir de 1976. Observaciones al trabajo de Francisco Delich," in El Poder militar en la Argentina, 1976-1981, eds. Waldmann and Garzón Valdés (Buenos Aires: Galerna, 1983).

6. Álvaro Abós, Las organizaciones sindicales y el poder militar (Buenos Aires: CEAL, 1984). Also relevant was Alvaro Abós, La columna vertebral. Sindicatos y Peronismo (Buenos Aires: Hyspamérica, 1983).

7. Fernández, Arturo, Las prácticas sociales del sindicalismo, 1976-1982 (Buenos Aires: CEAL, 1985).

8. Pablo Pozzi, Oposición obrera a la dictadura, 1976-1982 (Buenos Aires: Contrapunto, 1988) and "Argentina 1976-1982: Labour Leadership and Military Government," Journal of Latin American Studies 20(1): (1988) 111-38.

9. Pozzi, Oposición obrera a la dictadura.

10. He stressed that while they formally abided by the rules that only allowed individual actions at the factory, they were in fact subverting those orders by developing a collective action. Pozzi, Oposición obrera a la dictadura, chapters 3-5. Other relevant contributions on this aspect were Osvaldo Calello and Daniel Parcero, De Vandor a Ubaldini, 2 Vols. (Buenos Aires: Centro Editor de América Latina, 1984) and Chaves, Gonzalo Leónidas, Las luchas sindicales contra el Proceso, 1976-1980. Cinco años de resistencia (Buenos Aires: Ediciones de la Causa, 1983).

11. Delich, "Desmovilización social" and "Después del diluvio, la clase obrera."

12. Ricardo Falcón, "La resistencia obrera a la dictadura militar. Una reescritura de un texto contemporáneo a los acontecimientos," in A veinte años del golpe. Con memoria democrática, (comps.) Quiroga, Hugo y Tcach, César (Rosario, Homo Sapiens, 1996); James Petras, "El terror y la hidra: el resurgimiento de la clase trabajadora argentina" in James Petras, Clase, Estado y Poder en el Tercer Mundo (Mexico: Fondo de Cultura Económica, 1986), 286 and 295.

13. Francisco Delich, "Después del diluvio, la clase obrera," 146.

14. Alejandro Schneider. “'Ladran Sancho ...' Dictadura y clase obrera en la zona norte del Gran Buenos Aires," in De la Revolución Libertadora al Menemismo. Historia social y política argentina, (comp.) Pablo Pozzi, Hernán Camarero y Alejandro Schneider (Buenos Aires: Ediciones Imago Mundi, 2000), 195 and 231; Rafael Bitrán and Alejandro Schneider, "Dinámica social y clase trabajadora durante la dictadura militar de 1976-1983. Estudio de la zona norte del Gran Buenos Aires en particular de las fábricas Del Carlo y Ford Motors," in Nuevas tendencias en el sindicalismo: Argentina y Brasil, eds. L. M. Rodríguez et al. (Buenos Aires: Biblos-Simón Rodríguez, 1992); María Cecilia Cangiano, "What did it mean to be a revolutionary? Peronism, Clasismo and the steel workers of Villa Constitución. Argentina, 1945-1996" (Ph.D. dissertation, SUNY Stony Brook, 1996).

15. Manuel Barrera and Gonzalo Fallabella (comps.), Sindicatos bajo regímenes militares. Argentina, Brasil, Chile (Santiago de Chile: CES-Naciones Unidas, 1990).

16. Bernardo Gallitelli and Andrés Thompson, "La política laboral en la Argentina del "Proceso," in Sindicatos bajo regímenes militares. Argentina, Brasil, Chile, (comps.) Manuel Barrera y Gonzalo Fallabella (Santiago de Chile: CES-Naciones Unidas, 1990).

17. See Paul W. Drake, Labor Movements and Dictatorships. The Southern Cone in Comparative Perspective (Baltimore: Johns Hopkins University Press, 1996).

18. Drake admits that this view prompts the question: "If, with the partial exception of Chile, labor unions and parties in South America presented no irresistible threat to the established order, why were they viewed as such dangerous enemies who had to be curtailed?" In 
order to answer this question, he offers five possible explanations: (1) "these were conservative societies... and therefore, even mild challenges from the organized working class and its political partners appeared inordinately threatening;" (2) "the mobilization, politicization and radicalization of the workers movement were represented in an exaggerated fashion...by panicky opponents... and idealistic proponents of labor movements;" (3) "the dread of communism embodied in Latin America by the Cuban Revolution;" (4) the fact that there was "a militant minority of worker maximalists had emerged....and the ruling elites reacted to that dangerous minority by punishing all labor unions and parties;" and finally (5) the fact that in Spain, Brazil, Chile, and Argentina, pro-labor governments took power before the coups (and) those administrations permitted and encouraged a very unusual level of worker stridency." Drake, Labor Movements and Dictatorships, 25-26.

19. Ronald Munck, Authoritarianism and democratization. Soldiers and workers in Argentina, 1976-1983 (Pennsylvania: The Pennsylvania State University, 1998), 65.

20. Also in this period contributions from the field of economics and economic history were crucial for labor studies. From the 1990s to after 2001 there were lines of interpretation that illuminated crucial aspects of the economic and social transformations. See among others Eduardo Basualdo, Estudios de historia económica argentina. Desde mediados del siglo XX a la actualidad (Buenos Aires: Siglo Veintiuno, 2006).

21. The DIPBA Archive is the first intelligence archive open for researchers in Argentina. It provides access to documents that were elaborated with surveillance purposes over half a century. Documentation corresponds to 1932-1998, although systematic documental collections are concentrated between 1957-1998. In 2000, Provincial Law 12,642 declassified the archive's documentation and transferred its management to the Comisión por la Memoria of the Provice of Buenos Aires. In October 2003, the archive opened its doors to the public. For more about the DIPBA Archive see: http://www.comisionporlamemoria.org/archivo-dipba.htm.

22. Intelligence sources have particularities that require special cautions in order to preserve the privacy of individuals mentioned. See Ludmila Da Silva Catela, "Etnografía de los archivos de la represión en Argentina," in Historia reciente. Perspectivas y desafios para un campo en construcción, eds. Marina Franco and Florencia Levín (Buenos Aires, Paidós, 2007), 183-220 and Ludmila Da Silva Catela and Elizabeth Jelin (comps.), Los archivos de la represión: documentos, memoria y verdad (Madrid-Buenos Aires: Siglo XXI Editores, 2002), among others.

23. For more information about the CEDINCI and its collections, see: http://www.cedinci. org/.

24. FLACSO, CELS, PVyJ and SDH, Responsabilidad empresarial en delitos de lesa humanidad. Represión a trabajadores durante el terrorismo de estado (Buenos Aires, Infojus, 2015); Lorenz, Federico, "Los trabajadores navales de Tigre. La militancia sindical en un contexto de enfrentamiento 'militar." Lucha Armada 2(March-May 2005): 72-87. Federico Lorenz, Los zapatos de Carlito. Una historia de los trabajadores navales de Tigre en la década del 70 (Buenos Aires: Norma, 2007); Marina Lascano, "Cambios y continuidades en la clase obrera argentina entre 1973 y 1983. Una aproximación a través del caso de Ford Motors Argentina S.A." (Master thesis, Maestría en Ciencias Sociales UNG-IDES, 2013); Gabriela Weber, La conexión alemana. El lavado de dinero nazi en Argentina (Buenos Aires: Edhasa, 2005); Florencia Rodríguez, "Estrategias de lucha en industrias dinámicas durante la segunda ISI. Un análisis a partir del estudio de caso de Mercedes-Benz Argentina," in La clase trabajadora argentina en el siglo XX: experiencias de lucha y organización, ed. Basualdo, Victoria (Buenos Aires, Cara o ceca, 2011); Héctor Barbero, "La resistencia obrera en los anales de la policía bonaerense. El caso Mercedes Benz Argentina" (Informe final, Centro Cultural de la Cooperación, 2006); Ianina Harari and Sebastián Guevara, "Los efectos de la política represiva de la dictadura militar sobre la acción obrera: un análisis de los conflictos en Mercedes-Benz entre 1973 y 1983" en e-l@tina, 13(50) (Buenos Aires, Jan.-March 2015). Available at: http://publicaciones.sociales.uba.ar/index.php/elatina; Victoria Basualdo, Tomás Ojea Quintana and Carolina Varsky, "The cases of Ford and Mercedes Benz Argentina," in The Economic Accomplices of the Argentine Dictatorship: Outstanding Debts, eds. Horacio Verbitsky and Juan Pablo Bohoslavsy (Cambridge, United Kingdom: Cambridge University Press, 2015), 159-173; Victorio Paulón, "Acindar and Techint: Extreme Militarization of Labor Relations," in The Economic Accomplices of the Argentine Dictatorship, eds. Verbitsky and Bohoslavsy (Cambridge: Cambridge University Press, 2015), 174-185; Bernardo Veksler, La batalla de los Hornos (Buenos Aires, 2014). 
25. Agustín Prospitti, "Combatividad, dictadura y resistencia a la flexibilización laboral: Reconfiguraciones en la estrategia sociopolítica de la UOM Villa Constitución. 1970-1992", Cuadernos del Ciesal No 10, July-Dic. 2011; Nuria Giniger, "Así se templó el acero. Estrategias de control laboral y respuestas sindicales en el emplazamiento sidero-metalúrgico de Villa Constitución. Implicancias dentro y fuera de la fábrica" (Tesis Doctoral, Universidad de Buenos Aires, 2011); Victoria Basualdo, Labor and structural change: shopfloor organization and militancy in Argentine industrial factories (1943-1983)" (Ph.D. dissertation, Columbia University, 2010); Andrés Carminati, "La dirección de SOMISA durante la última dictadura militar, 1976-1983. Del restablecimiento de la disciplina en el trabajo al fundamento de la república democrática," in H-industria. Revista de la historia de la industria, los servicios y las empresas en América Latina, Year 5, N 8, first semester 2001; Simonassi, Silvia, “'A trabajar y muzzarella'. Prácticas y políticas de disciplinamiento laboral en la industria metalúrgica de Rosario, 1974-1983," in Historia Regional, No 25 (Villa Constitución, 2007).

26. FLACSO, CELS, PVyJ and SDH, Responsabilidad empresarial; Ivonne Barragán, "Prácticas y formas de resistencia de los trabajadores. Astillero Río Santiago 1974-1984", Tesis de Licenciatura, Departamento de Historia, Universidad Nacional de Mar del Plata, 2009; Alejandra Esponda, "De la dictadura a los '90, y de los '90 a la dictadura. Legados e impactos sobre la clase trabajadora y sus posibilidades de organización en el lugar de trabajo", in Basualdo, Victoria, La clase trabajadora argentina en el siglo XX: experiencias de lucha y organización (Buenos Aires, Cara o Ceca, 2011), 2,011; Ivonne Barragán, "Acción obrera durante la última dictadura militar. La represión en una empresa estatal: Astilleros Río Santiago, 1974-1984," in Basualdo, La clase trabajadora argentina en el siglo XX; Gabriela Mitidieri, "Evocando el pasado, construyendo la memoria. Las trabajadoras de Alpargatas Barracas en la huelga de Abril de 1979" in Revista Herramienta (Buenos Aires, 2012). Available at: http://www.herramienta.com.ar/revista-herramienta-n-51/evocando-elpasado-construyendo-la-memoria-las-trabajadoras-de-alpargatas-b, Gabriela Mitidieri, "La huelga de Alpargatas en 1979: las nociones de lo justo en dictadura," Revista Paginas 6 (Universidad Nacional de Rosario, Rosario, 2014).

27. FLACSO, CELS, PVyJ and SDH, Responsabilidad empresarial; Ana Belén Zapata, "Necesitaban gente que estuviese en el oficio..." Del olor a plomo al olor a tinta en los talleres gráficos de La Nueva Provincia (1973-1976) in Basualdo, La clase trabajadora argentina en el siglo $X X$; Daniel Dicósimo, "Disciplina y conflicto en la Historia durante el Proceso de Reorganización Nacional (1976-1983)" (Tesis Doctoral inédita en Historia, Universidad Nacional del Centro, 2007), Daniel Dicósimo, "Dirigentes Sindicales, racionalización y conflictos durante la última dictadura militar" in Revista Entrepasados, Año XV(29) (Buenos Aires, 2006).

28. FLACSO, CELS, PVyJ and SDH, Responsabilidad empresarial; Laura Ortiz, "Represión y resistencia en las fábricas" en Al filo, edición especial, (Córdoba, FFyH-UNC, marzo 2016). Available at: http://www.ffyh.unc.edu.ar/alfilo/especial-24marzo/represionresistenciafabricas/; Ana Elisa Arriaga "Represión sindical y disciplinamiento laboral: La violencia en el dispositivo de control del conflicto en EPEC (1973-1978)," in Córdoba a 40 años del golpe. Estudios de la dictadura en clave local, ed. Ana Carol Solís y Pablo Ponza (Editorial Filosofía y Humanidades de la FFYL, UNC, 2016), 75-104; http://www.ffyh.unc.edu.ar/editorial/wp-content/uploads/2013/05/EBOOK_40A\%C3\%91OSGOLPE.pdf.

29. FLACSO, CELS, PVyJ and SDH, Responsabilidad empresarial; Pablo J. Schamber. "Éxito y ocaso de un estilo de gestión empresarial. El caso del Establecimiento Las Marías en el sector yerbatero" in Revista Realidad Económica No 181 (Buenos Aires, July-August 2001).

30. FLACSO, CELS, PVyJ and SDH, Responsabilidad empresarial; Alejandra Dandan and Hannah Franzki, "Between Historical Analysis and Legal Responsibility: The Ledesma Case," in The Economic Accomplices of the Argentine Dictatorship: Outstanding Debts, eds. Horacio Verbitsky and Juan Pablo Bohoslavsy (Cambridge University Press, 2015); Gabriela A. Karasik and Elizabeth L. Gómez, "La empresa Ledesma y la represión en la década de 1970. Conocimiento, verdad jurídica y poder en los juicios de lesa humanidad," in Clepsidra. Revista Interdisciplinaria de Estudios sobre Memoria (Argentina, 2015); Delia Maisel, Rebeliones mineras. Lucha sindical en Mina Aguilar Jujuy (Buenos Aires: Nuestra América, 2013).

31. FLACSO, CELS, PVyJ and SDH, Responsabilidad empresarial; Gonzalo Pérez Álvarez, "Dictadura, democracia y clase obrera: los trabajadores ante el retorno al régimen 
constitucional en el noreste de Chubut”, Avances del CESOR (Rosario, 2015); Gonzalo Pérez Álvarez, "Juego, resistencia y cultura obrera en la Patagonia Argentina: el fútbol ante contextos represivos" Nuevo Mundo Mundos Nuevos [on-line], (March 2013), accessed 24/08/2017: http:// nuevomundo.revues.org/65161; doi: 10.4000/nuevomundo.65161.

32. Federico Lorenz's studies, for example, about the case of Astarsa, a shipyard in San Fernando, in the northern industrial belt of Buenos Aires, attempt to understand the reasons and ways in which a group of combative workers could build connections with Montoneros militants and the Juventud Trabajadora Peronista (JTP), and the ways in which this influenced and modified the course of their labor struggles, as well as the course and impact of the repressive policies. Federico Lorenz, “'Por la buena o por la mala' Militancia sindical y violencia política entre los trabajadores navales de la Zona Norte, 1973-1975" in Basualdo Victoria (comp.) La clase trabajadora argentina en el siglo XX: experiencias de lucha y organización (Buenos Aires, Editorial Cara o Ceca, 2011); Lorenz, Los zapatos de Carlito and Federico Lorenz, Algo parecido a la felicidad. Una historia de la lucha de la clase trabajadora durante la década del setenta (Buenos Aires, Editorial Edhasa, 2013); Victoria Basualdo and Federico Lorenz, "Los trabajadores industriales argentinos en la primera mitad de la década del 70: propuestas para una agenda de investigación a partir del análisis de casos," Revista Páginas, (Escuela de Historia UNR- CONICET, 2012). Available at: http://web.rosario-conicet.gov.ar/ojs/index.php/ RevPaginas/article/viewFile/177/207.

33. Basualdo, "Labor and structural change: shop-floor organization and militancy."

34. Daniel Cieza, El componente antisindical del terrorismo de Estado (Buenos Aires, Secretaría de Derechos Humanos, 2012). Available at: http://www.jus.gob.ar/media/1129181/ 42-anm-componente_antisindical.pdf; Emilio Crenzel, "Representaciones sobre los obreros desaparecidos: la lectura del Nunca Más", in Juan Besse, Emilio Crenzel, Luciana Messina and Miriam Wlosko, Memoria y trabajadores, Cuadernos de trabajo 2 (Lanús, Universidad Nacional de Lanús, 2013). Available at: http://www.repositoriojmr.unla.edu.ar/descarga/ MON/Besse_J_Memoria_2013.pdf; Inés Izaguirre (dir.), Lucha de clases, guerra civil y genocidio en la Argentina, 1976-1983. Antecedentes, desarrollo, complicidades (Buenos Aires, Eudeba, 2009); Daniel Feierstein, El genocidio como práctica social. Entre el nazismo y la experiencia argentina (Buenos Aires, Fondo de Cultura Económica, 2007).

35. See for example Pablo Pozzi, "Historia oficial y memoria obrera: Argentina 19761983," Antiteses 6:12 (jul-dic. 2013): 15-34; Pablo Pozzi, "Argentina, 1976-1983: la oposición obrera a la dictadura en la memoria de cinco trabajadores," en Revista Páginas Year 6:11 (2014): 7-26; Eleonora Bretal, "Memorias y experiencias de obreros/as de la carne sobre una época 'brava': los compañeros que se iban yendo y la 'degradación' del Swift en Berisso" in THEOMAI No 24, 2011; Victoria Basualdo, "Memoria e historia: desafíos en la elaboración e interpretación de testimonios en la reconstrucción de la historia reciente de los trabajadores industriales argentinos," in Memoria y reconstrucción de la paz. Enfoques multidisciplinares en contextos mundiales, eds. Rosa María Medina Doménech, Beatriz Molina Rueda, and María García-Miguel (Madrid: Ediciones de la Catarata, 2008); Victoria Basualdo, "Militancia y organización obrera de base durante la primera mitad de los años '70: una aproximación desde la historia oral al caso de Alpargatas en Florencio Varela," in Historia reciente, género y clase trabajadora: cinco estudios para pensar un problema de investigación, eds. Karin Grammatico, Mariela Marini and Wanda Weschler (Florencio Varela, UNAJ ediciones, 2016), among many others.

36. A very valuable early contribution about exile and labor was Daniel Parcero, Marcelo Helfgot, and Diego Dulce, La Argentina exiliada (Buenos Aires: CEAL, 1985). In terms of recent contributions, see Mónica Gatica, ¿Exilio, migración, destierro? Trabajadores chilenos en el noreste de Chubut (1973-2010) (Buenos Aires: Prometeo, 2013); Victoria Basualdo, "Una aproximación al exilio obrero y sindical," in Exilios. Destinos y experiencias bajo la dictadura militar, eds. Pablo Yankelevich y Silvina Jensen (Buenos Aires: Libros del Zorzal, 2007).

37. Celina Bonini, "El exilio interior. ¿Qué es el otoño?," Revista Taller 4:4 (1999): 128-39; Victoria Basualdo, "El exilio interno durante la última dictadura militar argentina: una aproximación," II Coloquio de historia y memoria (La Plata, 2006).

38. Victoria Basualdo, "The ILO and the Argentine dictatorship, 1976-1983," in ILO Histories. Essays on the International Labour Organization and Its Impact on the World During the Twentieth Century, eds. Jasmien Van Daele, Magaly Rodríguez García, Geert Van Goethem, and Marcel van der Linden (Berlín and Nueva York, Peter Lang, 2010); Victoria Basualdo, "La participación de trabajadores y sindicalistas en la campaña internacional 
contra la última dictadura militar argentina," Revista Sociedad No. 25 (Facultad de Ciencias Sociales de la Universidad de Buenos Aires, Spring 2006); Victoria Basualdo, "Dictadura militar, sindicalismo combativo y relaciones internacionales: apuntes para una historia reciente de los trabajadores industriales," in Antología. A treinta años del golpe (Secretaría de Cultura de la Nación Argentina-Central de los Trabajadores Argentinos, 2006).

39. Luciana Zorzoli, "Los sindicatos y el gobierno militar. Un estudio de sus relaciones a partir de la participación en la Organización Internacional del Trabajo (1976-1983)" (Tesis doctoral defendida en la Facultad de Ciencias Sociales de la Universidad de Buenos Aires, 2016); Luciana Zorzoli, "Operativo Ginebra. La dirigencia sindical ante la instalación internacional de la dictadura militar," Revista Archivos, Year IV(8): (2016) 13-32; Victoria Basualdo, "Contributions for the analysis of the participation of sectors of the trade-union leadership in labor repression in Argentina during the 1970s," in The Economic Accomplices of the Argentine Dictatorship, eds. Verbitsky and Bohoslavsy (Cambridge: Cambridge University Press, 2015), 201-216.

40. Victoria Basualdo, "Complicidad patronal-militar en la última dictadura argentina: Los casos de Acindar, Astarsa, Dálmine Siderca, Ford, Ledesma y Mercedes Benz," in Revista Engranajes de la Federación de Trabajadores de la Industria y Afines (Buenos Aires, 2006); Horacio Verbitsky and Juan Pablo Bohoslavsy (eds.), The Economic Accomplices of the Argentine Dictatorship: Outstanding Debts (Cambridge University Press, 2015).

41. FLACSO, CELS, PVyJ and SDH, Responsabilidad empresarial.

42. See among others Mitidieri, "Evocando el pasado, construyendo la memoria. Las trabajadoras de Alpargatas Barracas en la huelga de Abril de 1979"; Ivonne Barragán, "Mujeres trabajadoras y delegadas sindicales en un astillero de la Armada Argentina. Astillero Río Santiago (1973-1978)", REVISTA NOMADíAS Number 20 (Dec. 2015) 227-248; Ivonne Barragán and Florencia Rodríguez, "Clase, género, politización y violencia. Los casos del Astillero Río Santiago y Propulsora Siderúrgica 1974-1975", in Revista de Estudios Marítimos y Sociales, Year 5/6, Number 5/6, (Nov. 2012/3) 41-51; Grammatico, Marini and Weschler (coords.), Historia reciente, género y clase trabajadora: cinco estudios para pensar un problema de investigación; and Débora D'Antonio, La prisión en los años 70. Historia, Género y Política (Buenos Aires, Biblos, 2016), and "Controversial images of women during the last argentinian military dictatorship. 1976-1983", in Journal of Latin American Cultural Studies, Great Britain Oxfordshire, Volume 13, Number 3 (Dec. 2004) 375-393.

43. Peter Winn, Victims of the Chilean Miracle: Workers and Neoliberalism in the Pinochet Era, 1973-2002 (Durham, NC: Duke University Press, 2004).

44. See among many others Felipe Venero, "Trabajadores y dictadura. Un balance crítico sobre la producción historiográfica," in Clase obrera, sindicatos y Estado, Argentina 1955-2010, (coords.) Alejandro Schneider and Pablo Ghigliani (Buenos Aires: Imago Mundi, 2015); Andrés Carminati, "Algo habrán hecho". La historia de los trabajadores durante la última dictadura militar (1976-1983). Un repaso historiográfico," Historia Regional, Sección Historia, ISP No 3, Año XXV(30): (2012) 13-34.

45. For conceptual definitions of perspectives referring to "consent" and "consensual" positions, see Daniel Dicósimo, "La delgada línea roja. Conflicto y consentimiento en las relaciones laborales (1976-83)," en Historia Regional, Sección Historia, ISP No 3, Año XXV(30): (2012) 35-49, and Los trabajadores argentinos y la última dictadura. Oposición, desobediencia y consentimiento (Buenos Aires, UNICEN, 2016). For a discussion see Victoria Basualdo (with the collaboration of Ivonne Barragán and Florencia Rodríguez), "La clase trabajadora durante la última dictadura militar argentina (1976-1983). Apuntes para una discusión sobre la resistencia obrera" (La Plata, Comisión Provincial por la Memoria, 2010) and Victoria Basualdo, "Nuevas aproximaciones al estudio de la última dictadura militar: sus aportes y limitaciones para la historia de la clase trabajadora", IV Seminario Internacional sobre Políticas de la Memoria, Centro Cultural Haroldo Conti, (Buenos Aires, 2011). Available at: http://conti.derhuman.jus.gov.ar/2011/10/mesa_1/basualdo_mesa_1.pdf.

46. On the debate on the concept of "resistance," see Basualdo, "La clase trabajadora durante la última dictadura military argentina" and Daniel Dicósimo, "La resistencia de los trabajadores a la última dictadura militar. Un aporte a su conceptualización" in Avances del Cesor, XII(13): (second semester 2015) 71-93; Marisa Gallego, "Clase obrera, dictadura y resistencia (1976-1983)," in Historia social e historia oral. Experiencias en la historia reciente de Argentina y América Latina, (comp.) Laura Pasquali (Homo Sapiens Ediciones, Rosario, 2008), Daniel Dicósimo y Andrés Carminati, "Sabotaje a la dictadura. Un estudio sobre las formas de 
sabotaje industrial durante la última dictadura militar en el Gran Rosario y el centro sudeste bonaerense (1976-1983)," Anuario IEHS 28: (2013) 257-78, among others.

47. Victoria Basualdo and Alejando Jasinski, "La represión a los trabajadores y el movimiento sindical," in Represión estatal y violencia paraestatal en la historia reciente argentina: nuevos abordajes a 40 años del golpe de estado, Gabriela Águila, Santiago Garaño and Pablo Scatizza (La Plata: FAHCE-UNLP, 2016); Ivonne Barragán and Ana Belén Zapata, "Dictadura militar y represión a la clase trabajadora. La Armada Argentina, marco doctrinario y operaciones represivas en perspectiva regional para los casos de Ensenada y Bahía Blanca," in Diacronie. Studi di Storia Contemporanea 24:4 (2015) Available at: http://www.studistorici.com/ 2015/12/29/barragan-zapata_numero_24/; Ana Belén Zapata and Laura Rodríguez Agüero, "Violencia paraestatal en Mendoza y Bahía Blanca (1973-1976). Un enfoque comparativo," in Clepsidra. Revista Interdisciplinaria de Estudios sobre Memoria vol. 4 (Buenos Aires, 2017), Alejandro Ernesto Asciutto, "Represión en Campana: el caso de la Dálmine Siderca," in Negocios y dictadura. La conexión argentino italiana, eds. Alejandro Ernesto Asciutto, Cecilia Hidalgo and Inés Izaguirre (Buenos Aires: Imago Mundi, 2017).

48. Besides classic books such as Daniel James, Resistance and integration. Peronism and the Argentine working class, 1946-1976 (Cambridge: Cambridge University Press, 1988) and Schneider, Alejandro, Los compañeros. Trabajadores, izquierda y peronismo, 1955-1973. (Buenos Aires, Ediciones Imago Mundi, 2006), new approaches made important contributions, such as Sebastián Chiarini and Rosa Elsa Portugheis (coords.), Plan Conintes. Represión política y sindical (Archivo Nacional de la Memoria, Secretaría de Derechos Humanos, Ministerio de Justicia y Derechos Humanos de la Nación, 2014); Silvia Nassif, Tucumán en llamas. El cierre de ingenios y la lucha obrera contra la dictadura (1966-1973) (Tucumán: Facultad de Filosofía y Letras UNT, 2016) among many others. Other recent contributions illuminated ways to analyze the dictatorship in terms of long-term labor legislation or the changes of the tradeunion movement, such as Luis Campos, Estado y sindicatos: un análisis de sus relaciones a partir de los mecanismos de regulación y la conformación de la estructura sindical en la Argentina (1943-1988), MA Thesis, Maestría en Economía Política de FLACSO (2009), Nicolás Damin, Derechos, organizaciones sindicales y políticas: 1930-1983 (Remedios de Escalada, Universidad Nacional de Lanús, 2017). 